\title{
Kriptokokal meningitis: Aspek klinis dan diagnosis laboratorium
}

\author{
Efrida, Desiekawati
}

\section{Abstrak}

Kriptokokosis merupakan infeksi yang disebabkan oleh jamur Cryptococcus neoformans, infeksi ini secara luas ditemukan di dunia dan umumya dialami oleh penderita dengan sistem imun yang rendah. Munculan klinis terutama adalah meningitis dan meningoensefalitis yang dikenal dengan kriptokokal meningitis.

Sejalan dengan infeksi HIV yang menjadi pandemi, kriptokokosis sebagai infeksi oportunistik juga semakin berkembang di dunia. Kriptokokal meningitis merupakan infeksi oportunistik kedua paling umum yang terkait dengan AIDS di Afrika dan Asia Selatan dengan kejadian kriptokokosis 15\%-30\% ditemukan pada pasien dengan AIDS. Tanpa pengobatan dengan antifungal yang spesifik, mortalitas dilaporkan $100 \%$ dalam dua minggu setelah munculan klinis kriptokokosis dengan meningoensefalitis pada populasi terinfeksi HIV. Di Indonesia, sebelum pandemi AIDS kasus kriptokokosis jarang dilaporkan. Sejak tahun 2004, seiring dengan pertambahan pasien terinfeksi HIV, Departemen Parasitologi FKUI mencatat peningkatan insidensi kriptokokal meningitis pada penderita AIDS yaitu sebesar $21,9 \%$.

Faktor yang terkait dengan virulensi Cryptococcus neoformans adalah adanya kapsul polisakarida, produksi melanin dan sifat thermotolerance. Imunitas yang dimediasi oleh sel memiliki peranan penting dalam pertahanan pejamu terhadap Cryptococcus.

Pemeriksaan laboratorium penunjang untuk diagnosis adalah pemeriksaan mikroskopis langsung menggunakan tinta India, deteksi antigen, metode enzyme immunoassay, kultur, dan metode molekular.

Kata kunci: kriptokokal meningitis, Cryptococcus neoformans,infeksi oportunistik

\section{Abstract}

Cryptococcosis is an infection caused by Cryptococcus neoformans, that is widely found worldwide and generally experienced by patients with immunodeficiency. Meningitis and meningoencephalitis is the major clinical symptoms in cryptococcal meningitis.

Coincide with the pandemic of HIV infection, cryptococcosis as an opportunistic infection is also growing in the world. Cryptococcal meningitis is the second most common opportunistic infection associated with AIDS in Africa and South Asia with the incidence of cryptococcosis is $15 \%-30 \%$ found in patients with AIDS. Without specific antifungal treatment, $100 \%$ mortality reported within two weeks after clinical cryptococcosis with meningoencephalitis in HIV-infected population. In Indonesia, before the AIDS pandemic, cryptococcosis cases are rarely reported. Since 2004, by the increasing HIV-infected patients. Department of Parasitology Faculty of Medicine, Indonesian University also reported an increase incidence of cryptococcal meningitis in AIDS patients that is about $21.9 \%$.

Associated factors with virulence of Cryptococcus neoformans is the polysaccharide capsule, melanin production and thermotolerance. Cell-mediated immunity has an important role in host defense against Cryptococcus.

Laboratory tests for cryptococcosis diagnosis is direct microscopic examination using India ink, antigen detection, enzyme immunoassay, culture, and molecular methods.

Keywords: cryptococcal meningitis, Cryptococcus neoformans, opportunistic infection

Affiliasi penulis : Bagian Patologi Klinik Fakultas Kedokteran Universitas Andalas Padang

Korespondensi : Efrida, Bagian Patologi Klinik Fakultas Kedokteran Universitas Andalas Padang. pdspatklin pdg@yahoo.com Telp: 0751-841514

\section{Pendahuluan}

Kriptokokosis merupakan infeksi yang disebabkan oleh jamur Cryptococcus neoformans. Infeksi ini secara luas ditemukan di dunia dan umumnya dialami oleh penderita dengan sistem imun yang rendah, seperti penderita human immunodeficiency virus/acquired immunodeficiency syndrome (HIV/AIDS), pasien dengan pengobatan kortikosteroid jangka panjang, transplantasi organ, dan keganasan limforetikuler. Infeksi oleh Cryptococcus neoformans terutama menyebabkan meningitis dan meningoensefalitis pada orang yang terinfeksi

\section{HIV/AIDS didiagnosis sebagai kriptokokal meningitis. $^{1,2}$}

Lima sampai sepuluh persen orang yang terinfeksi HIV menderita kriptokokosis, insidensi tahunan penyakit ini adalah 0,4-1,3 kasus perseratus ribu orang pada populasi umum, 2-7 kasus perseribu pasien AIDS, dan 0,3-5,3 kasus perseratus pasien yang menjalani transplantasi. ${ }^{2}$

Kriptokokal meningitis adalah manifestasi klinis yang paling sering ditemukan merupakan infeksi oportunistik kedua paling umum yang terkait dengan AIDS di Afrika dan Asia Selatan dengan kejadian kriptokokosis $15 \%-30 \%$ ditemukan pada pasien dengan AIDS. Tanpa pengobatan dengan antifungal yang spesifik, mortalitas dilaporkan $100 \%$ dalam dua minggu setelah munculan klinis kriptokokosis dengan meningoensefalitis pada populasi terinfeksi HIV. ${ }^{1,3}$ 
Cryptococcus dikenal dengan istilah sleeping giant yang sekarang dibangunkan oleh pandemi AIDS. Di Indonesia, sebelum pandemi AIDS kasus kriptokokosis jarang dilaporkan. Sejak tahun 2004, seiring dengan pertambahan pasien terinfeksi HIV, Departemen Parasitologi FKUI mencatat peningkatan insidensi kriptokokal meningitis pada penderita AIDS yaitu sebesar 21,9\%. Rumah Sakit Persahabatan Jakarta pada tahun 2006 mendiagnosis dua kasus pasien dengan kriptokokosis paru. Di Bandung, Akhmad tahun 2008 melaporkan 30\% pasien AIDS dengan gangguan sistem saraf pusat terbukti menderita meningitis Cryptococcus. Di Padang kasus penderita AIDS dengan kriptokokosis yang dilaporkan adalah ditemukannya pertama kali satu kasus di Laboratorium Patologi Anatomi Fakultas Kedokteran Universitas Andalas tahun 2007. 4,5,6

Pada tinjauan pustaka ini akan dibahas patogenesis, diagnosis, dan pemeriksaan laboratorium kriptokokal meningitis.

\section{Cryptococcus neoformans}

\section{Sejarah}

Cryptococcus pertama kali ditemukan pada tahun 1894 oleh Busse dan Buschke yang melaporkan satu kasus pada seorang perempuan usia 31 tahun yang mempunyai ulkus berukuran besar pada tibianya dan ditemukan pembesaran kelenjar getah bening. Busse mengobservasi bentuk seperti jamur pada pemeriksaan lesi secara histologi dan kemudian mengkultur jamur tersebut yang awalnya disebut sebagai Saccharomyces. Isolasi pertama Cryptococcus dari lingkungan dilaporkan pada tahun 1894 sewaktu Sanfelice mengisolasi jamur dari buah persik dan dinamakan Saccharomyces neoformans. Pada tahun 1901 Vuillemin mengganti nama jamur itu menjadi Cryptococcus hominis untuk membedakannya dari bentuk Saccharomyces spp. Pada tahun 1976, Kwon-Chung menemukan dan menggolongkan sebagai basidiomycete dan dinamakan Filobasidiella neoformans. Akhirnya pada tahun 2003 seluruh genom

C. neoformans dapat ditentukan.,

Kasus kriptokokal meningitis pertama yang dipublikasi adalah pada seorang perempuan usia 29 tahun yang didiagnosis dengan gejala keterlibatan leptomeningen seperti digambarkan oleh Verse pada tahun 1914. Dua kasus meningitis dilaporkan pada tahun 1916 oleh Stoddard dan Cutler; pada pemeriksaan patologi jaringan sistem saraf pusat postmortem didapatkan bentuk jamur dengan daerah terang disekelilingnya. ${ }^{7,8}$

\section{Morfologi dan Serotipe $C$. neoformans}

Cryptococcus neoformans adalah organisme dimorfik, merupakan basidiomisetes yang bersifat saprofit, ditemukan di seluruh dunia karena habitatnya adalah pada kotoran burung dan tanah yang terkontaminasi kotoran burung. Basidiospora berukuran kecil yaitu 1,8 $\mu \mathrm{m}$ sampai $3,0 \mu \mathrm{m}$, dapat dalam bentuk sel ragi pada suhu $37^{\circ} \mathrm{C}$ atau membentuk hifa dikariotik pada suhu $24^{\circ} \mathrm{C} .^{9,10,11}$

Secara mikroskopis Cryptococcus neoformans di dalam jaringan atau cairan spinal berbentuk sferis sampai oval dengan diameter $3 \mu \mathrm{m}$ $10 \mu \mathrm{m}$, sering bertunas (budding) dan dikelilingi oleh kapsul yang tebal. Pada agar Sabouraud dengan suhu kamar, koloni yang terbentuk berwarna kecoklatan, mengkilat, dan mukoid. ${ }^{12}$

Cryptococcus neoformans diklasifikasikan kedalam lima serotipe ( $A, B, C, D$, dan $A D)$ dan tiga varietas yaitu $C$. neoformans var. neoformans (serotipe D), C. neoformans var. grubii (serotipe A), dan C. neoformans var. gattii (serotipe B dan C). Pembagian serotipe berdasarkan perbedaan epitop pada kapsulnya dan perbedaan reaksi aglutinasi pada kapsul sesuai dengan polisakaridanya. Perbedaan varietas ini berdasarkan pada kemampuan varietas gattii dalam menggunakan glisin atau prolin sebagai sumber nitrogen satu-satunya sedangkan varietas neoformans/grubii tidak. Varietas gattii juga resisten terhadap canavanine sedangkan varietas neoformans/grubii biasanya sensitif. Kesanggupan dalam menggunakan glisin dan ketahanan terhadap canavanine digunakan dalam membedakan varietas gattii dengan varietas neoformans/grubii. Pada Tabel berikut ditampilkan perbedaan $C$. neoformans varietas neoformans dan varietas gattii. ${ }^{7,13}$

Tabel Perbedaan C. neoformans var. neoformans dengan var. gatii ${ }^{7}$

\begin{tabular}{lllll}
\hline Varietas & Serotipe & Resisten & Glisin sbg & Bentuk \\
& & Canava & sumber & basidiospora \\
& & nine & nitrogen & \\
& & & satu-satunya & \\
\hline neoformans & A dan D & Tidak & Tidak & berentetan \\
\hline gattii & B dan C & Ya & Ya & bentuk elips \\
\hline
\end{tabular}

\section{KRIPTOKOKAL MENINGITIS}

\section{Definisi dan Transmisi Kriptokokal Meningitis}

\section{a. Definisi}

Kriptokokal meningitis adalah infeksi jamur yang disebabkan oleh jamur berkapsul genus Cryptococcus yaitu Cryptococcus neoformans yang mengenai sistem saraf pusat dengan gejala meningitis dan meningoensefalitis. Penyakit ini muncul sebagai kasus sporadis yang tersebar di seluruh dunia, merupakan infeksi oportunistik terutama terjadi pada individu immunocompromised (umumnya pada penderita HIV/AIDS), tetapi kasus dapat juga terjadi pada individu yang imunokompeten. ${ }^{13,14}$

\section{b. Transmisi Penyakit}

Transmisi penyakit ini terjadi secara inhalasi. Basidiospora terhirup bersama debu lingkungan, biasanya terdapat di sekitar tempat tenggeran merpati, pada kayu yang lapuk, dan tanah yang terkontaminasi 
kotoran burung. Penyakit ini tidak ditularkan langsung dari orang ke orang melalui jalur respirasi atau dari binatang ke manusia. C. neoformans banyak terdapat pada lingkungan yang tercemar kotoran burung atau kelelawar, tetapi burung tersebut tidak terinfeksi. Transmisi terjadi melalui jalur pulmonal dan menyebar secara hematogen sampai ke target utamanya pada sistem saraf pusat. ${ }^{7,8}$

\section{Epidemiologi}

Kriptokokosis tidak hanya merupakan penyakit infeksi yang umumnya berakibat fatal pada individu yang immunocompromised tetapi Cryptococcus juga merupakan suatu patogen pada individu imunokompeten. Mortalitas pasien HIV terkait meningitis yang disebabkan oleh Cryptococcus cukup tinggi yaitu sekitar 10\%-30\%. Suatu analisis kohor pasien dengan infeksi HIV di Afrika menunjukkan persentase kriptokokosis adalah $13 \%-44 \%$ dari semua penyebab kematian. Defek sistem imun yang dimediasi oleh sel $\mathrm{T}$ (seperti penderita AIDS) merupakan faktor predisposisi pada $80 \%-90 \%$ pasien dengan infeksi Cryptococcus. Insidensi kriptokokosis juga meningkat pada pasien dengan keganasan limforetikular (khususnya penyakit Hodgkin's). ${ }^{1,15}$

\section{Patogenesis dan Patofisiologi}

Infeksi berawal dari inhalasi sel ragi kecil atau basidiospora yang memicu terjadinya kolonisasi pada saluran nafas dan kemudian diikuti oleh infeksi. Makrofag pada paru-paru sangat penting dalam sistem kontrol terhadap inokulasi

jamur. Makrofag dan sel dendritik berperan penting dalam respons terhadap infeksi Cryptococcus. Sel ini berperan dalam pengenalan terhadap jamur, dalam fagositosis, presentasi antigen, dan aktivasi respons pada pejamu, serta meningkatkan efektivitas opsonisasi fagositosis terhadap jamur. Pada sel dendritik reseptor mannose berperan penting untuk pengenalan jamur dan presentasi antigen terhadap sel $T$, sel ini bereaksi dengan $C$. neoformans dan mengekspresikannya ke limfosit kemudian bermigrasi ke jaringan limfoid. Makrofag memberikan respons terhadap $C$. neoformans dengan melepaskan sitokin proinflamasi yaitu IL-1. Sekresi IL-1 mengatur proliferasi dan aktivasi limfosit $T$ yang penting dalam memediasi pembersihan paru. ${ }^{8,16}$

Imunitas yang dimediasi oleh sel memiliki peranan penting dalam pertahanan terhadap Cryptococcus. Pada banyak kasus penyebaran kriptokokosis terjadi pada keadaan defisiensi sel T CD4+ (HIV/AIDS), imunitas dihubungkan dengan respons sel Th1 yang aktif menghancurkan $C$. neoformans. Sel CD4+ dan CD8+ berperan pada jaringan yang terinfeksi. Limfosit T CD4+ dan CD8+ secara langsung menghambat pertumbuhan jamur melalui perlekatan terhadap permukaan sel Cryptococcus. Kurangnya atau tidak adanya respons imun yang baik untuk menginaktifkan dan menghancurkan organisme yang masuk menyebabkan perluasan dan peningkatan kerusakan sel/jaringan akibat infeksi. ${ }^{8,15}$

\section{a. Kapsul Polisakarida Sebagai Faktor Virulensi}

Kapsul polisakarida berperan penting dalam kemampuan bertahan hidup Cryptococcus terhadap lingkungan dan menimbulkan penyakit pada manusia. Kapsul ini mengandung hampir $90 \%$ polisakarida glucuronoxylomannan (GXM), 9\% galactoxylomannan (GalXM), dan 1\% mannoprotein. Kapsul polisakarida ini membantu organisme tersebut menghindar dari respons sistem imun, yaitu melindungi patogen dari fagositosis dan penghancuran oleh neutrofil, monosit, dan makrofag. Kapsul ini dapat menghambat migrasi leukosit dari aliran darah ke tempat inflamasi sehingga berguna dalam invasi organisme dan memudahkan berkembangnya infeksi. Kapsul tersebut juga berperan terhadap deplesi komplemen, kurangnya respons antibodi, dan disregulasi sekresi sitokin oleh makrofag termasuk TNF- $\alpha$ dan IL-6. ${ }^{13}$

Komponen yang terdapat pada kapsul dilepaskan selama $C$. neoformans mengalami replikasi, GXM diakui sebagai gambaran pengenalan reseptor yang ditemukan pada berbagai sel imunitas alamiah seperti makrofag dan sel dendritik. Mannoprotein merupakan peptida yang imunodominan yang akan berperan sebagai pengenalan oleh sel $T$ spesifik antigen. Mannoprotein melibatkan reaksi respons imun IFN- $y$ dan respons hipersensitif tipe lambat, keduanya merupakan hal yang perlu dalam aktivasi klasik makrofag dan membersihkan jamur. ${ }^{9,17}$

\section{b. Melanin Sebagai Faktor Virulensi}

Adanya melanin pada dinding sel $C$. neoformans menimbulkan adaptasi jamur terhadap perubahan lingkungan seperti radiasi ultraviolet dan temperatur yang ekstrim. Melanin menimbulkan daya tahan jamur selama proses infeksi, melindungi jamur dari reactive oxygen species dan berperan sebagai suatu antioksidan. Melanin juga berperan untuk integritas dinding sel yang penting dalam proteksi terhadap agen antijamur pada permukaan sel. ${ }^{9}$

Peranan melanin dalam interaksi antara pejamu dan patogen adalah bahwa melanin kemungkinan melindungi sel patogen karena efek antioksidan serta oleh adanya efek pada permukaan dinding sel yang merupakan perlindungan terhadap sejumlah efektor imunitas selular. Melanin yang diproduksi ini meningkatkan virulensi Cryptococcus. Suatu penelitian terhadap model tikus menunjukkan bahwa sel-sel tikus dengan melanin lebih resisten terhadap fagositosis. ${ }^{13,18,19}$

\section{c. Patogenesis Meningoensefalitis oleh $C$. neoformans}

Mekanisme masuknya organisme ini ke dalam sistem saraf pusat yang menyebabkan meningoensefalitis tidak diketahui secara jelas. Beberapa hipotesis yang mendukung dalam menjelaskan mekanismenya adalah bahwa jamur melewati sawar darah otak. 
Jamur masuk melalui endotel sawar darah otak yang tersusun atas sel endotel mikrovaskular otak. Penelitian oleh Ibrahim et al., pada tahun 1995 menunjukkan bahwa $C$. neoformans mempunyai kemampuan untuk melekat ke sel endotel dan kemudian mengalami internalisasi pada sel endotel, selanjutnya menyebabkan kerusakan sel endotel. Tiga mekanisme yang memungkinkan Cryptococcus melewati sawar darah otak dan memasuki sistem saraf pusat yaitu: (1) melewati mekanisme transselular langsung, cryptococci diinternalisasi oleh sel endotel dan keluar melalui permukaan abluminal sel; (2) mekanisme Trojan Horse, menerangkan bahwa cryptococci diliputi oleh sel fagositik pada awal infeksi dan kemudian dilewatkan oleh sel pejamu ke sistem saraf pusat; dan (3) transfer langsung dari fagosit yang terinfeksi ke dalam sel endotel dan kemudian diikuti oleh pengeluarannya melalui permukaan abluminal sel. Adanya infeksi oleh virus HIV akan memfasilitasi Cryptococcus melewati sawar darah otak dan akan mengganggu integritas sawar darah otak dan/atau oleh aktivitasnya yang berperan sebagai suatu transpredilection factor. $^{13}$

\section{Manifestasi Klinis Kriptokokal Meningitis}

Paru merupakan gerbang utama tempat masuknya Cryptococcus neoformans. Infeksi primer pada paru sering asimptomatik, namun gejala bervariasi tergantung pada faktor pejamu, inokulum, dan virulensi organisme sehingga penyakit dapat menyebar secara sistemik dengan tempat predileksi utamanya adalah pada otak. Gejala penyakit ini bisa asimptomatis sampai yang berat yaitu meningitis. ${ }^{7,12}$

Secara umum kriptokokosis pada paru dapat menimbulkan gejala seperti batuk, nyeri dada, pleuritis, demam, sesak nafas, dan sindrom distres pernafasan akut (terutama pada pasien immunocompromised). ${ }^{14}$

Meningitis merupakan manifestasi paling sering kriptokokosis, peradangan ini juga disertai dengan peradangan parenkim otak sehingga istilah meningoensefalitis lebih tepat digunakan. Kriptokokal meningitis harus selalu dimasukkan dalam diagnosis diferensial pada kasus meningoensefalitis kronis atau subakut karena gambaran klinis yang tidak spesifik. $^{12,14}$

Pada pasien HIV, penyakit ini dikaitkan dengan adanya imunosupresi, biasanya pada keadaan jumlah CD4 $<100$ sel/ $\mu \mathrm{L}$ dan kurangnya respons inflamasi yang dilihat dari jumlah leukosit $<20 / \mu \mathrm{L}$ dengan titer antigen Cryptococcus serum yang tinggi. $^{14}$

\section{PEMERIKSAAN LABORATORIUM Cryptococcus neoformans}

Pemeriksaan $C$. neoformans yang akan dibahas pada tinjauan ini adalah pemeriksaan mikroskopis langsung menggunakan tinta India, deteksi antigen, metode enzyme immunoassay, kultur, dan metode molekular.

\section{Praanalitik Pemeriksaan}

Syarat pengumpulan sampel untuk pemeriksaan laboratorium, pemeriksaan mikroskopis langsung, pemeriksaan kultur, dan serologi adalah sebagai berikut: $^{14}$

- sampel diambil secara aseptis sebelum pemberian antifungal, dikumpulkan pada wadah yang steril dan segera dibawa ke laboratorium

- sampel diambil sesegera mungkin setelah timbulnya gejala yang mendukung ke arah diagnosis

- jumlah sampel yang dianjurkan untuk cairan serebrospinal (CSS) adalah $>2 \mathrm{~mL}$. Sampel darah 10-20 mL untuk dewasa dan 4-10 mL untuk anak-anak

Pengiriman, penyimpanan, dan pemrosesan sampel adalah sebagai berikut:

- sampel harus dikirim sesegera mungkin ke laboratorium, waktu maksimum yang dibolehkan untuk transpor adalah sampai 24 jam pada suhu kamar untuk sampel yang diambil pada tempat yang steril

- sesampai di laboratorium sampel harus diproses sesegera mungkin, sampel diproses dalam waktu kurang dari empat jam, untuk isolasi Cryptococcus sampel tidak boleh disimpan di refrigerator. Untuk pemeriksaan serologi dan molekular, spesimen yang tidak langsung diperiksa dapat disimpan pada refrigerator selama dua minggu dan dapat disimpan beku selama satu bulan.

- sampel cairan serebrospinal disentrifus pada tabung sentrifus yang steril selama 10 menit pada 2000-2500 rpm, supernatan kemudian dituangkan ke wadah lain dan disimpan untuk deteksi antigen. Pelet digunakan untuk membuat sediaan hapus dan basah serta untuk kultur.

\section{Pemeriksaan Mikroskopis Langsung}

Metode yang digunakan untuk pemeriksaan mikroskopis langsung adalah pewarnaan dengan tinta India dan dibaca dengan mikroskop cahaya, merupakan pemeriksaan yang dilakukan untuk mendeteksi kapsul sel jamur C. neoformans. ${ }^{14}$

\section{Pewarnaan dengan Tinta India}

Persiapan pewarnaan $C$. neoformans dengan Tinta India adalah:

- disiapkan kaca objek yang bersih dan tidak berminyak

- diteteskan 1 tetes tinta India pada bagian tengah kaca objek

- diambil spesimen (CSS) satu loop, lebih baik sedimen hasil sentrifus dengan loop yang sudah dipijarkan dan didinginkan terlebih dahulu 
- kedua tetesan dicampurkan dengan loop atau jarum steril, kemudian tetesan tersebut ditutup dengan kaca penutup

- sediaan diperiksa dengan mikroskop cahaya. Pada pembesaran 400x Cryptococcus neoformans terlihat sebagai titik-titik bercahaya pada latar belakang gelap sedangkan dengan pembesaran 1000x sel terlihat mengandung badan refraktil yang dikelilingi oleh kapsul tebal, karakteristik adalah adanya budding yang menegaskan untuk diagnosis.

\section{Deteksi Antigen C. neoformans dengan Aglutinasi Lateks}

Prinsip Pemeriksaan

Partikel lateks yang dilapisi dengan anticryptococcal globulin reagent (ACGR) akan bereaksi dengan antigen cryptococcus dalam serum atau cairan serebrospinal pasien. Apabila terdapat antigen cryptococcus dalam sampel yang diperiksa maka akan terbentuk/terlihat aglutinasi. ${ }^{19}$

\section{Pemeriksaan Berdasarkan Metode Enzyme Immunoassay}

Penelitian klinis menunjukkan bahwa enzyme immunoassay digunakan sebagai metode pendukung untuk pengukuran antibodi IgG pada kriptokokosis. Literatur menyatakan metode untuk mendeteksi antibodi Cryptococcus yang ada sekarang kurang spesifik dan kurang sensitif. Tes aglutinasi tabung mendeteksi hanya 30\% pasien dengan Cryptococcus, immunofluorescence assay (IFA) mendeteksi kira-kira $38 \%$ kasus dengan Cryptococcus. Gabungan kedua pemeriksaan tersebut direkomendasikan dengan kemampuan mendeteksi kira-kira $50 \%$ kasus kriptokokosis. ${ }^{11}$

\section{Kultur Cryptococcus}

Diagnosis kriptokokosis dikonfirmasi dengan melakukan kultur organisme yang merupakan baku emas dalam diagnosis laboratorium. Media yang paling umum digunakan untuk kultur jamur adalah Sabouraud's Dextrose Agar (SDA). Sabouraud's Dextrose Agar digunakan untuk isolasi dan penanaman jamur. ${ }^{18}$

\section{a. Kultur pada Sabouraud's Dextrose Agar}

Prinsip Pemeriksaan:

Sabouraud's Dextrose Agar merupakan media yang mengandung pepton, glukosa, dan dengan $\mathrm{pH}$ rendah yang optimal bagi jamur. Pepton merupakan sumber nitrogen sedangkan glukosa merupakan sumber energi untuk pertumbuhan jamur. Glukosa dalam konsentrasi tinggi memberikan suatu keuntungan dalam pertumbuhan jamur. ${ }^{19}$

\section{b. Kultur pada Birdseed (NIGER) Agar}

Birdseed agar merupakan media selektif, media diferensial yang digunakan untuk isolasi dan identifikasi $C$. neoformans dari jamur lainnya termasuk dari spesies cryptococcus yang lain. $^{20}$

Prinsip pemeriksaan:

Cryptococcus neoformans mempunyai aktivitas phenoloksidase, terdapat di dalam dinding sel yang mampu memetabolisme asam caffeic. Guizotia abysinics seeds berfungsi sebagai substrat phenoloksidase. $C$. neoformans menghasilkan enzim dalam substrat yang akan dikonversi menjadi melanin atau pigmen seperti melanin menghasilkan warna coklat gelap, sedangkan jamur lain menghasilkan sangat sedikit atau bahkan tidak menghasilkan enzim sehingga tidak terjadi perubahan warna. ${ }^{20}$

\section{Metode Secara Molekular}

Pendekatan diagnostik secara molekular yaitu deteksi DNA dengan amplifikasi secara Polymerase chain reaction (PCR) dan amplifikasi hasil PCR dideteksi secara elektroforesis. ${ }^{11}$

\section{RINGKASAN}

Kriptokokosis merupakan infeksi yang disebabkan oleh jamur berkapsul genus Cryptococcus yaitu Cryptococcus neoformans. Infeksi ini secara luas ditemukan di dunia, merupakan infeksi oportunistik terutama terjadi pada individu immunocompromised (umumnya penderita HIV/AIDS) dengan manifestasi klinis yang utama adalah kriptokokal meningitis. Kriptokokal meningitis dapat mengenai penderita dengan sistem imun rendah lainnya seperti pasien dengan pengobatan kortikosteroid jangka panjang, transplantasi organ, dan keganasan limforetikular.

Transmisi penyakit ini terjadi secara inhalasi melalui basidiospora yang terhirup bersama udara dan debu lingkungan yang terkontaminasi, kemudian masuk ke paru. Infeksi primer pada paru sering asimptomatik, namun gejala bervariasi tergantung pada faktor pejamu, inokulum, virulensi organisme sehingga penyakit dapat menyebar secara sistemik dengan tempat predileksi utamanya adalah pada otak. Gejala penyakit ini bisa asimptomatis sampai yang berat yaitu meningitis/meningoensefalitis.

$$
\text { Pemeriksaan laboratorium dalam }
$$
menegakkan kriptokokal meningitis adalah pemeriksaan mikroskopis langsung dengan tinta India, pemeriksaan antigen dengan aglutinasi lateks, pemeriksaan enzyme immunoassay untuk deteksi antibodi, kultur jamur, dan pemeriksaan biomolekular.

\section{DAFTAR PUSTAKA}

1. Bicanic T and Harrison TS. Cryptococcal Meningitis. Br Med Bull. 2004; 72: 99-118.

2. Centers for Disease Control and Prevention (CDC). Cryptococcosis Technical Information [serial online] 2003. Diunduh dari http://www.cdc.gov/ncidod/dbmd/diseaseinfo/ cryptococcosis t.htm dilihat tanggal 12 Oktober 2011 
3. Park BJ, Wannemuehler KA, and Marston BJ. Estimation of The Current Global Burden of Cryptococcal Meningitis Among Person Living with HIV/AIDS. AIDS. 2009; 23: 52530.

4. Syahruddin E dan Herman D. Kriptokokosis Paru Primer. Departemen Pulmonologi dan Ilmu Kedokteran Respirasi FKUI. Jakarta. J Respir Indo. 2007; 27(2): 120-24.

5. Tofrizal, Nizar RZ, Esther HM. Kriptokokosis. Bagian Patologi Anatomi, Fakultas Kedokteran Universitas Andalas, Padang; 2007.

6. Wahyuningsih R. Ancaman Infeksi Jamur pada Era HIV/AIDS. Maj Kedokt Indon. 2009; 59:12. Departemen Parasitologi FKUI dan Bagian Parasitologi FKUI.

7. Perfect JR and Cox GM. Cryptococcosis. In Microbiology and Microbial Infections, Medical Mycology. $9^{\text {th }}$ ed. Editors. Merz WG and Hay RJ. American Society for Microbiology, Washington DC; 2005. hlm. 637-53.

8. Voelz K. Macrophage-Cryptococcus Interactions During Cryptococcosis. College of Life and Environmental Sciences School of Biosciences. University of Birmingham; 2010.

9. Whiteway $M$ and Bachewich C. Fungal Genetics in Fungi: Biology and Applications. Editor, Kevin Kavanagh. Department of Biology National University of Ireland Maynooth Co. Kildare, Ireland. John Wiley \& Sons, Ltd; 2005. hlm. 36-63.

10. Karkowska-Kutela J, Rapala-Kozik M, and Kozik A. Fungi Pathogenic to Humans: Molecular Bases of Virulence of Candida albicans, Cryptococcus neoformans and Aspergillus fumigatus. Department of Analytical Biochemistry, Faculty of Biochemistry, Biophysics, and Biotechnology, Jagiellonian University, Krakow, Poland. Review. 2009; 56 (2): 211-224.

11. Prince Y. Literature Review of Cryptococcus neoformans in Improving Laboratory Diagnostic Techniques to Detect $M$. Tuberculosis Complex and $C$. neoformans as The Causitive Agents of Chronic Meningitis in The Cerebrospinal Fluid of Adult Patients. Medical Microbiology at Stellenbosch University; 2010.

12. Kayser, FH. Fungi as Human Pathogens in General Mycology. Color Atlas of Medical Microbiology. Editor: Kayser FH, Bienz KA, Eckert J, Zinkernagal RM. Thieme, New York: 2005. hlm. 348-74.

13. Ma $\mathrm{H}$ and May RC. Virulence in Cryptococcus Species in Advances in Applied Microbiology. Editors: Laskin Al, Sariaslani S, Gadd GM, Vol. 67, Burlington Academic Press; 2009. hlm. 131-90.
14. WHO. Laboratory Manual for Diagnosis of Fungal Opportunistic Infections in HIV/AIDS Patients. Regional Office for South-East Asia, New Delhi; 2009.

15. Office of Public Health, Louisiana Dept of Health \& Hospitals. Cryptococcosis in Infectious Disease Epidemiology Section. 2004.

16. Shoham $S$ and Levitz SM. The Immune Response to Fungal Infections. British Journal of Haematology. Blackwell Publishing Ltd; 2005; 129: 569-82.

17. Pietrella D, Corbucci C, Perito S, Bistoni G, and Vecchiarelli A. Mannoproteins from Cryptococcus neoformans promote Dendritic Cell Maturation and Activation. Infect Immun. 2005; 73: 820-27.

18. Winn Jr W, Allen S, Janda W, Koneman E, Procop G, Schreckenberger P et al. Mycology in Koneman's Color Atlas and Texbook of Diagnostic Microbiology, 6th ed. Philadelphia, Lippincott Williams \& Wilkins; 2006. hlm. 1151-1243.

19. BD Diagnostic Systems. BD ${ }^{T M}$ Sabouraud Glucose Agar. Instructions for Use-Ready to Use Plated Media. 2009.

20. PML Microbiologicals. Birdseed (Niger) Agar. Technical Data Sheet \#170 REV. 3; 2008 